\title{
LANGUE BAHASA INDONESIA UNTUK MENGEMBANGKAN KREATIVITAS MAHASISWA
}

\author{
Dheka Dwi Agustiningsih ${ }^{1}$, Erik Rusmana ${ }^{2}$ \\ Universitas Islam Bandung ${ }^{1}$ \\ Universitas Pasundan ${ }^{2}$ \\ ddagusti@unisba.ac.id ${ }^{1}$, erik.rusmana@unpas.ac.id ${ }^{2}$
}

\begin{abstract}
Abstrak
Tulisan ini membahas Bahasa Indonesia sebagai salah satu mata kuliah umum di perguruan tinggi. Ditingkat universitas mata kuliah ini termasuk dalam rumpun mata kuliah pengembangan kepribadian. Oleh sebab itu, tujuan dari mata kuliah ini tidak sebatas pada kemampuan menggunakan kaidah bahasa dalam berkomunikasi. Tulisan ini bertujuan untuk menunjukkan bahwa pada tataran langue, bahasa Indonesia dapat digunakan untuk mengembangkan kreativitas mahasiswa. Konsep mengenai langue ini sebagaimana yang dikemukakan oleh Saussure. Di dalam konsep ini terdapat relasi sintagmatik dan asosiatif yang dapat digunakan untuk mengembangkan kreativitas mahasiswa melalui karya tulis ilmiah. Metode yang digunakan dalam penelitian ini adalah deskriptif kualitatif. Berdasarkan analisis yang telah dilakukan ditemukan bahwa melalui pencarian konstituen yang memiliki relasi sintagmatik dan asosiatif baik berupa kata, frasa, dan kalimat, maka ide baru dapat ditemukan dan kreativitas dapat dikembangkan lalu diwadahi dalam bentuk karya tulis ilmiah.
\end{abstract}

Kata kunci: langue, sintagmatik, asosiatif, konstituen

\section{Abstract}

This paper discussed about Bahasa Indonesia as one of the general course in higher education. In university this subject include in personality development. Therefore, the purpose of this subject is not limited to the ability to use the rules of language in communication. This paper aims to show that at the level of langue, Indonesian can be used to develop student creativity. The concept of this langue as proposed by Saussure. Within this concept there is a syntagmatic and associative relationships that can be used to develop student creativity through scientific papers. The method used in this research is descriptive qualitative. Based on the analysis that already conducted, found that through a search of constituents which have syntagmatic and associative relations in the form of words, phrases, and sentences, then we can found the new ideas and creativity can be developed and contained in the form of scientific papers.

Key words: langue, syntagmatic, associative, constituent

\section{Pendahuluan}

Bahasa Indonesia di tingkat perguruan tinggi khususnya bagi program sarjana dan diploma merupakan salah satu mata kuliah umum yang wajib ada dalam kurikulum sebagaimana diamanatkan dalam UU No. 12 Tahun 2012 tentang Pendidikan Tinggi, Pasal 35 ayat (3). Adapun dalam kurikulum baru tahun 2006 sesuai SK Dirjen Dikti Depdiknas RI No. 43/DIKTI/Kep/2006, Bahasa Indonesia termasuk dalam Mata Kuliah Pengembangan Kepribadian (MPK). Dengan demikian, pencantuman mata kuliah Bahasa Indonesia dalam kurikulum Perguruan Tinggi itu dimaksudkan sebagai: (1) media pembelajaran kemampuan berbahasa Indonesia para mahasiswa, dan (2) salah satu sarana pengembangan kepribadian para mahasiswa. 
12 Agustiningsih \& Rusmana, Langue Bahasa Indonesia untuk Mengembangkan Kreativitas Mahasiswa

Jadi, idealnya perkuliahan Bahasa Indonesia bertujuan untuk membantu mahasiswa menguasai dan menerapkan kaidah bahasa dalam komunikasi lisan dan tulis. Selain itu, ditujukan pula untuk mengembangkan diri dan pribadi mahasiswa. Kedua hal tersebut jika dikaitkan dengan ilmu bahasa sebagaimana yang digagas oleh Saussure maka akan berkaitan dengan bahasa dalam tataran langue dan parole (2003). Langue dapat diartikan sebagai suatu sistem tanda yang mengungkapkan gagasan misalnya bahasa tertentu yang merupakan sebuah produk masyarakat (Saussure, 1993: 88). Sementara itu, parole adalah jumlah dari apa yang dituturkan orang dan mengandung kombinasi individual dan tindak pembunyian yang sukarela (Saussure, 1993: 87).

Penguasaan dan kemampuan mahasiswa dalam menggunakan kaidah bahasa dalam komunikasi berkaitan dengan tataran parole. Tataran parole merupakan bahasa yang diucapkan dan digunakan anggota masyarakat dalam kegiatan sehari-hari (Chaer, 2004). Penggunaan ragam bahasa baku dalam penulisan karya ilmiah merupakan bagian dari kegiatan sehari-hari.

Karya tulis ilmiah dapat menjadi wahana mahasiswa untuk mengembangkan kreativitas. Kreativitas merupakan suatu kemampuan untuk menciptakan suatu yang baru, sebagai kemampuan untuk memberikan gagasan-gagasan baru yang dapat diterapkan dalam pemecahan masalah, atau sebagai kemampuan untuk melihat hubungan-hubungan baru antara unsur-unsur yang sudah ada (Munandar, 2004). Melalui karya tulis ilmiah, ide, ilmu, rasa ingin tahu, kreativitas, dan energi dapat bermuara.

Menulis merupakan kompetensi yang harus dipelajari oleh mahasiswa menurut Alwasilah (2000: 678-679). Menulis perlu dilakukan untuk mengartikulasikan berbagai pengalaman, termasuk pengalaman ilmiah. Berdasarkan hasil survey yang dilakukan Indonesian Education Sector Survey Report, dijelaskan bahwa pendidikan di Indonesia menekankan pada keterampilan-keterampilan rutin dan hafalan (Juliantine, 2009: 3). Anak tidak didorong mengajukan pertanyaan dan menggunakan daya imajinasinya untuk mencari jawaban-jawaban terhadap masalah atau menunjukkan banyak inisiatif. Padahal pentingnya kreativitas tertera dalam Sistem Pendidikan Nasional No 20 Tahun 2003.

Kreativitas dapat menjadi salah satu aspek pengembangan kepribadian yang dapat dikaitkan dengan langue. Melalui langue, kreativitas seorang manusia dapat dikembangkan. Hal ini berkaitan dengan relasi sintagmatik dan asosiatif sebagaimana yang diungkapkan Saussure (1993: 219).

Sintagma selalu dibentuk oleh dua atau sejumlah satuan berurutan. Sintagma tidak hanya berlaku bagi kata, tetapi juga bagi kelompok kata, bagi satuan apapun dan jenis apapun 
seperti kata majemuk, kata turunan, anggota suatu kalimat, bahkan seluruh kalimat (Saussure, 1993: 221). Menurut Chaer relasi sintagmatik adalah hubungan yang terdapat antara satuan bahasa di dalam kalimat yang konkret (2004: 19). Misalnya dalam kalimat Dia mengikut ibunya terdapat 15 buah fonem yang berkaitan dengan cara tertentu; tiga buah kata dengan hubungan tertentu pula; dan ada tiga fungsi sintaksis yaitu subjek, predikat, dan objek yang memiliki hubungan tertentu pula. Hubungan sintagmatis tersebut bersifat linear, atau horizontal antara satuan yang satu dengan yang lain yang berada di kiri dan kanannya.

Selain relasi yang didasari oleh sifat langue yang linear, ada pula relasi asosiatif. Relasi asosiatif adalah hubungan yang terdapat dalam bahasa tetapi tidak tampak dalam susunan satuan kalimat (Saussure, 1993: 223). Hubungan ini akan tampak bila dibandingkan dengan kalimat lain. Misalnya, kata mengikut yang terdapat dalam contoh di atas. Selain kata mengikut para penutur bahasa Indonesia mengetahui kata mengikuti, mengikutkan, kauikuti, kauikutkan, dan terikuti. Hubungan yang terdapat antara kata mengikut dengan kata mengikuti, mengikutkan, kauikuti, kauikutkan, dan terikuti seperti ini menurut Saussure merupakan relasi asosiatif.

Asosiatif berhubungan erat dengan masalah substitusi (dapat tidaknya penggantian suatu konstituen tertentu dalam kalimat tertentu dengan konstituen lainnya, misalnya dia dengan Ali, dengan mereka, mahasiswa, pejabat). Ada tiga macam substitusi dalam relasi asosiatif, yaitu: fonemis, morfemis, dan sintaksis. Substitusi fonemis menyangkut pergantian fonem dengan fonem lain, misalnya dalam pasangan minimal dari vs lari, kuda vs kura, dan tambal vs tambat. Distribusi morfemis menyangkut masalah pergantian sebuah morfem dengan morfem lain, misalnya mengikut vs diikut vs terikut, daya juang vs medan juang, tuna karya vs tuna wisma. Distribusi sintaksis menyangkut masalah pergantian kata dengan kata, frasa dengan frasa, atau klausa dengan klausa lainnya.

Penelitian terkait bahasa dan kreativitas pernah dilakukan oleh Karmila, Suharno, dan Purwadi (2011). Penelitian tersebut bertujuan untuk mengetahui tingkat kreativitas anak pada kelompok eksperimen sebelum atau sesudah perlakuan. Pada penelitian ini bahasa diposisikan sebagai metode pembelajaran dan secara khusus berbentuk permainan. Hasil penelitiannya menunjukkan bahwa metode permainan bahasa terbukti berpengaruh secara signifikan terhadap peningkatan kreativitas anak yang terlihat dari adanya perbedaaan secara signifikan pada tingkat kreativitas anak antara kelompok eksperimen yang diberikan perlakuan dengan kelompok yang diberikan perlakuan permainan bahasa. 
14 Agustiningsih \& Rusmana, Langue Bahasa Indonesia untuk Mengembangkan Kreativitas Mahasiswa

Penelitian lain yang serupa juga pernah dilakukan di bidang pendidikan jasmani. Julaintine (2009) melakukan penelitian eksperimen selama satu semester (12 kali pertemuan) terhadap siswa SD kelas V putra dan putri yang berasal dari tiga sekolah, yaitu SD Negeri Cisitu 1, 2, dan 3 yang berjumlah 100 orang. Hasil penelitiannya menunjukkan bahwa model pembelajaran inkuiri dapat mengembangkan kreativitas siswa SD daripada model pendidikan jasmani tradisional yang hanya menitikberatkan pada penguasaan teknik cabang olahraga.

Penelitian lain juga dilakukan di bidang Matematika (Supardi, 2012). Penelitian ini menggunakan penelitian survey terhadap 30 orang siswa dengan teknik purposive sampling. Hasil dari penelitian ini menunjukkan siswa yang tingkat berpikir kreatifnya tinggi akan berperan sebagai motivasi internal yang akan mendorong siswa agar lebih tertarik untuk belajar matematika.

Berdasarkan latar belakang di atas, penelitian ini bertujuan untuk menunjukkan langue dapat berfungsi untuk mengembangkan kreativitas mahasiswa melalui praktik menulis karya ilmiah.

\section{Metode}

Adapun metode yang digunakan dalam penelitian ini adalah deskriptif kualitatif. Dengan menggunakan metode ini, penulis berusaha menunjukkan langue dapat berfungsi untuk mengembangkan kreativitas mahasiswa melalui praktik menulis karya ilmiah. Untuk membahas rumusan di atas digunakan konsep langue dan parole, dan relasi sintagmatik dan asosiatif yang terdapat di dalam langue sebagaimana yang dikemukakan oleh Saussure (1993).

\section{Hasil dan Pembahasan}

\section{Relasi Sintagmatik dan Asosiatif dalam Mengembangkan Ide}

Salah satu aspek bahasa yang dikemukakan oleh Saussure adalah langue. Langue merupakan konvensi dan menjadi milik masyarakat. Hal ini dapat digunakan untuk mengembangkan kreativitas dalam menulis karya ilmiah melalui relasi sintagmatik dan asosiatif.

Dalam menulis karya ilmiah, ide merupakan hal dasar yang harus dimiliki. Untuk mendapatkan ide dapat digunakan analisis sintagmatik dan asosiatif dari sebuah kata atau kalimat. Misalnya, kalimat Ekstrak kulit manggis menyehatkan tubuh, dalam kalimat tersebut terdapat 35 fonem yang berkaitan, lima buah kata, dan ada tiga fungsi sintaksis yaitu subjek, 
predikat, dan objek yang memiliki hubungan. Hubungan sintagmatis dalam kalimat tersebut bersifat linear.

Sintagma yang berlaku dalam kalimat tersebut berupa kata, kelompok kata, bahkan seluruh kalimat. Sintagma yang berupa kata yaitu, ektrak, kulit, manggis, menyehatkan, dan tubuh. Sintagma yang berupa kelompok kata yaitu: kulit manggis, dan ektrak kulit manggis. Sementara itu, sintagma yang berupa kalimat yaitu Ekstrak kulit manggis menyehatkan tubuh.

Semua tipe sintagma yang dibangun dari bentuk-bentuk yang teratur tersebut termasuk dalam langue. Kosa kata yang digunakan adalah berbagai kata yang biasa digunakan oleh masyarakat juga dengan kaidah bahasanya (seperti fungsi Subjek-Predikat-Objek).

Di dalam langue terdapat dua hubungan yang mendasar yaitu hubungan sintagmatik dan asosiatif. Hubungan sintagmatik muncul karena sifat bahasa yang linear. Seseorang tidak dapat mengucapkan banyak kata dalam satu waktu. Dalam kalimat Ekstrak kulit manggis menyehatkan tubuh, setiap unsur (kata maupun kelompok kata) diucapkan satu persatu, mulai dari ekstrak hingga tubuh, sesuai dengan aturan yang telah ada dalam langue. Pada kalimat di atas, ekstrak-kulit-manggis- menyehatkan - tubuh- merupakan sintagma. Jadi, hubungan sintagmatis adalah hubungan mata rantai di dalam ujaran Ekstrak kulit manggis menyehatkan tubuh.

Sementara itu, hubungan asosiatif (paradigmatik) hadir di luar wacana karena katakata yang mempunyai kesamaan berasosiasi dalam pikiran. Asosiasi dalam pikiran membentuk kelompok-kelompok yang memiliki ciri yang sama, baik dari segi bentuk maupun maknanya. Dari segi bentuk, contohnya: membuat, pembuatan, buatan, pembuat. Dari segi makna, contohnya: ekstrak kulit manggis, ekstrak biji anggur, ekstrak kulit cacing. Ketiga kata itu mengacu pada kelompok yang sama, yaitu ramuan.

Langue dan hubungan yang terdapat di dalamnya dapat digunakan sebagai salah satu materi yang dapat mengembangkan kreativitas. Dengan menggunakan sebuah kalimat misalnya Ekstrak kulit manggis menyehatkan tubuh, mahasiswa bisa diajak membangun relasi sintagmatik dan asosiatif dengan cara mencari konstituen berupa kosakata yang dapat berdistribusi dalam kalimat tersebut. 
16 Agustiningsih \& Rusmana, Langue Bahasa Indonesia untuk Mengembangkan Kreativitas Mahasiswa

Tabel 1. Konstituen yang dapat digunakan dalam distribusi

\begin{tabular}{|c|c|c|c|c|}
\hline \multirow[t]{2}{*}{$\begin{array}{l}\text { Larutan } \\
\text { Ampas } \\
\text { Serbuk } \\
\text { Ekstrak } \\
\text { Sari }\end{array}$} & \multirow[t]{2}{*}{$\begin{array}{l}\text { Buah } \\
\text { Biji } \\
\text { Daun } \\
\text { Tangkai } \\
\text { Batang } \\
\text { Getah } \\
\text { Akar }\end{array}$} & $\begin{array}{l}\text { tomat } \\
\text { kubis } \\
\text { wortel } \\
\text { bayam } \\
\text { terong }\end{array}$ & \multirow[t]{2}{*}{$\begin{array}{l}\text { menghaluskan } \\
\text { memutihkan } \\
\text { mengencangkan } \\
\text { menyehatkan } \\
\text { menyegarkan } \\
\text { melindungi } \\
\text { membersihkan }\end{array}$} & \multirow[t]{2}{*}{$\begin{array}{l}\text { kulit } \\
\text { rambut } \\
\text { mata } \\
\text { bibir } \\
\text { perut } \\
\text { jantung } \\
\text { lambung } \\
\text { paru-paru }\end{array}$} \\
\hline & & $\begin{array}{l}\text { apel } \\
\text { anggur } \\
\text { jambu } \\
\text { sawo } \\
\text { jeruk } \\
\text { mangga } \\
\text { lengkeng } \\
\text { rambutan } \\
\text { melon } \\
\text { semangka }\end{array}$ & & \\
\hline ekstrak & kulit & manggis & menyehatkan & tubuh \\
\hline
\end{tabular}

Tabel di atas, secara horizontal kolomnya berisi unsur-unsur (kata dan kelompok kata) yang dapat dikombinasikan dan menjadi sebuah kalimat dan memiliki hubungan sintagmatik. Beberapa ide yang dapat dibangun berdasarkan hasil kombinasi konstituen yang memiliki relasi sintagma yaitu: Ektrak kulit semangka menyehatkan tubuh, Ektrak kulit melon menyehatkan tubuh, Ektrak kulit rambutan menyehatkan tubuh, Ektrak kulit lengkeng menyehatkan tubuh, Ektrak kulit mangga menyehatkan tubuh, Ektrak kulit jeruk menyehatkan tubuh, Ektrak kulit sawo menyehatkan tubuh, Ektrak kulit jambu menyehatkan tubuh, Ektrak kulit anggur menyehatkan tubuh, Ektrak kulit apel menyehatkan tubuh.

Distribusi konstituen lain dapat membangun ide baru. Misalnya jika bagian dari buah merupakan konstituen yang kemudian dikombinasikan dengan jenis buah akan menghasilkan beberapa ide lain, yaitu: Ektrak akar apel menyehatkan tubuh, Ektrak getah apel menyehatkan tubuh, Ektrak batang apel menyehatkan tubuh, Ektrak tangkai apel menyehatkan tubuh, Ektrak kulit daun menyehatkan tubuh, Ektrak biji apel menyehatkan tubuh, dan Ektrak buah apel menyehatkan tubuh.

Hal tersebut di atas baru merupakan kombinasi yang melibatkan konstituen berupa satu kata. Beberapa kalimat lain yang mungkin dihasilkan dari kombinasi konstituen di atas secara acak yaitu: Ektrak biji sawo menyehatkan kulit, Sari buah semangka menyegarkan rambut, 
Ampas biji mangga melindungi kulit, serbuk daun anggur menyehatkan paru-paru, Larutan kulit jambu menyehatkan tubuh.

Dalam kolom di atas terdapat beberapa kata lain yang dapat didistribusikan dan membangun relasi sintagmatik yang dapat memunculkan makna dan memicu ide baru. Katakata lain yang dapat didistribusikan yaitu: larutan, ampas, serbuk, ekstrak, sari, tomat, kubis, wortel, bayam, terong, menghaluskan, memutihkan, mengencangkan, menyehatkan, menyegarkan, melindungi, membersihkan, kulit, rambut, mata, bibir, perut, jantung, lambung, paru-paru.

Secara vertikal, kolom-kolom tersebut diisi dengan kata yang memiliki hubungan asosiastif. Kata serbuk, ampas, larutan, sari memiliki asosiasi pada makna bentuk ramuan. Kata kulit, akar, getah, batang, tangkai, daun, biji, buah, berasosiasi pada bagian-bagian tumbuhan buah. Kata semangka, melom, rambutan, lengkeng, mangga, jeruk, sawo, jambu, anggur, apel, berasosiasi pada buah-buahan lokal. Sementara itu, kata menyehatkan, menghaluskan, memutihkan, mengencangkan, menyehatkan, menyegarkan, melindungi, membersihkan pada makna keberfungsian. Lalu, kata paru-paru, lambung, jantung, perut, ibir, mata, rambut, dan kulit, dari segi makna memiliki asosiasi pada bagian tubuh. Selain kombinasi dari unsur-unsur, konstituen di atas juga memiliki hubungan asosiatif yaitu ramuan untuk kesehatan dan kecantikan.

Dari penjelasan di atas, dapatlah dikatakan akan adanya substitusi substitusi sintaksis. Distribusi sintaksis ini menyangkut masalah pergantian kata dengan kata, dan frasa dengan frasa. Jadi, konstituen-konstituen kalimat itu dapat dibandingkan atau diasosiasikan dengan bentuk bahasa yang lain.

Dengan mencari relasi sintagmatik dan asosiatif dari kata maupun kalimat, ide-ide baru dapat bermunculan. Jika saat ini banyak penelitian mengenai ektrak kulit manggis, maka ide lain yang serupa dapat mengemuka, misalnya ekstrak biji manggis, biji sawo, dan biji lainnya sebagaimana yang berada dalam kolom ketiga. Adapun bentuk ramuannya juga bisa beragam sebagaimana yang terdapat dalam kolom pertama, yaitu berbentuk sari, larutan, serbuk, atau ampas. Sementara itu, fungsi atau khasiat yang hendak dicapai dapat dilihat dalam kolom keempat. Dan bagian tubuh atau bagian tertentu yang hendak dikenai fungsi dapat dilihat dalam kolom kelima.

Hubungan sintagmatik dan paradigmatik di atas dapat digunakan untuk merangsang kreativitas seseorang dalam bidang apapun. Contoh di atas menunjukkan dapat dilakukannya eksplorasi ide melalui kosakata. Hasil dari eksplorasi kata dapat dilanjutkan pada inisiasi 
18 Agustiningsih \& Rusmana, Langue Bahasa Indonesia untuk Mengembangkan Kreativitas Mahasiswa

melakukan penelitian. Contoh di atas menunjukkan pula bahwa banyak sekali kekayaan alam, berupa bagian maupun jenis tumbuhan dan hasil buah yang dapat dimanfaatkan demi kemaslahatan masyarakat. Permasalahan kosmetik dan kesehatan barangkali dapat sedikit demi sedikit terjawab jika ide-ide segar terus dilahirkan.

Dalam praktiknya, pembelajaran dapat dilakukan dengan mengusung tema-tema tertentu sesuai minat dan bidang yang dipelajari oleh mahasiswa untuk merangsang lahirnya berbagai pemikiran yang dapat menjawab tantangan zaman. Melalui bahasa, kreativitas terus menerus dirangsang. Melalui asumsi baru yang dihasilkan dari melakukan analisis terhadap hubungan yang ada dalam suatu sintagma, proses penemuan dimulai. Hipotesis baru dapat dimunculkan. Namun, sebagai syaratnya kosakata harus terus menerus ditingkatkan jumlahnya karena hipotesis terbentuk dari gabungan informasi terdahulu dan kini.

Hipotesis harus dibuktikan. Ujicoba harus dilakukan karena kreativitas tidak selesai pada tercapainya pandangan atau wawasan baru melainkan membawa rasionalitas baru sebagai kepekaan terhadap masalah.

Bila ide sudah dilahirkan, uji coba dilakukan, maka sepanjang perjalanan hingga hipotesis dapat dibuktikan maka proses penulisan harus dilakukan. Penulisan tidak sekadar mencatat apa yang terjadi, tetapi merekam segala proses berpikir dan memindahkan realitas melalui kata-kata.

Menulis perlu dilakukan untuk mengartikulasikan berbagai pengalaman, dalam hal ini khususnya pengalaman ilmiah. Perlu dilakukan optimalisasi khususnya di lingkungan akademik untuk berkontribusi dalam meningkatkan produksi tulisan yang lebih lanjut akan bermuara pada meningkatnya reproduksi pengetahuan dan hadirnya sumber-sumber pengetahuan baru yang diharapkan dapat mencerdaskan bangsa dan membawa negara ini pada kondisi yang lebih baik.

\section{Kesimpulan}

Bahasa bukan hanya dipelajari sebatas teori tetapi harus digunakan sebagai pengembang kreativitas. Melalui relasi sintagmatik dan asosiatif hal tersebut dapat dilakukan. Berbagai konstituen dapat dihadirkan untuk membangun relasi tersebut dengan tujuan mencari sebanyak mungkin berbagai kombinasi kemungkinan untuk memunculkan ide yang menjadi dasar penulisan karya ilmiah. 
Kompetensi bahasa harus ditingkatkan, khususnya menulis. Melalui karya tulis ilmiah diharapkan ide dan kreativitas mahasiswa dapat diwadahi dan dikembangkan. Hal ini juga akan memicu produksi tulisan dan reproduksi pengetahuan. Selain itu, bahasa Indonesia perlu dipelajari sebagai sarana pembentuk karakter, menjadi alat berpikir dan pemicu kreativitas. 
20 Agustiningsih \& Rusmana, Langue Bahasa Indonesia untuk Mengembangkan Kreativitas Mahasiswa

\section{DAFTAR PUSTAKA}

Alwasilah, A. Chaedar. (2000) "Membenahi Pekuliahan MKDU Bahasa Indonesia di Perguruan Tinggi” dalam Bambang Kaswanti Purwo (ed), Kajian Serba Linguistik untuk Anton Moeliono Pereksa Bahasa. Jakarta: Gunung Mulia.

Chaer, Abdul. (2004). Linguistik Umum. Jakarta: Rineka Cipta.

Departemen Pendidikan Nasional Republik Indonesia. (2006) Keputusan Direktorat Jenderal Pendidikan Tinggi Nomor: 43/DIKTI/Kep/2006. Jakarta: Direktorat Jenderal Pendidikan Tinggi.

Juliantine, Tite. (2009). Pengembangan Kreativitas Siswa melalui Implementasi Model Pembelajaran Inquiri dalam Pendidikan Jasmani. Skripsi. Bandung: Universitas Pendidikan Indonesia.

Karmila, Mila, Suharno, Agus, dan Purwadi. (2011) "Pengaruh Metode Pembelajaran Permainan Bahasa Peningkatan Kreativitas Anak", Jurnal Paudni, Vol.1, No.1.

Munandar, Utami. (2004). Pengembangan Emosi dan Kreativitas. Jakarta: Rineka Cipta.

Munandar, Utami. (2004). Pengembangan Kreativitas Anak Berbakat. Rineka Cipta. Jakarta.

Republik Indonesia. (2012) Undang-Undang No. 12 Tahun 2012 tentang Pendidikan Tinggi.

Lembaran Negara RI Tahun 2012. Jakarta: Sekretariat Negara.

Saussure, Ferdinand de. Pengantar Linguistik Umum. Yogyakarta: UGM Press. 1993.

U.S., Supardi. (2012). "Peran Berpikir Kreatif dalam Proses Pembelajaran Matematika", Jurnal Formatif, Vol. 2, No. 3. 